evaporated to get rid of the gypsum, and afterwards further evaporated in vacuum pans, and run into barrels ready for crystallisation.

MATERIAL changes are officially reported from the Bay of Talcahuano, in Chile, which was surveyed by Captain Fitzroy. The commander of the Chilean war steamer Ancud now reports that the water throughout the entire extent of the bay has increased from two to two-and-a-half fathoms. This represents great geological change. The rock Fraile, in the Gulf of Arauco, represented on Fitzroy's chart as a sunken rock, is now, however, a small island united to the mainland, opposite to the western bank of the river Tubul, and has rather the shape of a quadrangular pyramid.

THE Times of India states that the coal-beds discovered in Bellary are excellent in quality and abundant in quantity. Great anxiety is felt for Dr. Oldham, who said he would eat all the coal found in the Madras Presidency, for the doctor is a man of honour.

From a considerable number of observations on the temperatures of the two sides of the body, Mr. Blake draws the following conclusions, which are recorded in the Medical Times and Gazette of October 8, 1870:-r. That the temperature of the sides of the trunk under usual circumstances, i.e. in health and at rest in a temperate climate, is equal. 2. That under certain conditions the temperature of the left side of the trunk may exceed that of the right. 3. That that excess during exertion in a cool atmosphere averages half a degree $F$. 4. That that excess reaches its maximum of about one degree $F$. during exertion under a powerful sun.

\section{THE GEOGRAPHICAL DISTRIBUTION OF} $D E E R^{*}$

I $\mathrm{N}$ his excellent "Geographische Mittheilungen," Dr. 1 Petermann has lately given us several zoo-geographical articles, as we may call them-such as those of Dr. Finsch on the distribution of Parrots, and of Freiherr von Heuglin on the Bird-fauna of North-eastern Africa. Both of these memoirs are the products of the highest authorities on the subjects to which they respectively relate, and deserve our warmest commendation. We cannot, however, say so much as to the merit of the paper upon the Geographical Distribution of Deer, which appears in a recent number of Dr. Petermann's journal. The authors of this memoir, which, if properly treated, is on a subject of very great interest, have, we fear, commenced to indulge in "generals" before having sufficiently got up their "particulars." In the first part of their essay they point out the present distribution of the different genera and species of Cervidee over the world's surface, and endeavour to show how they have descended from a common ancestral form. This form they imagine must have been the Moschida, upon the ground that in order to obtain a deer with horns we must pre-suppose the existence of a deer without horns, and the Moschida answer this definition. Unfortunately, however, the authors have not yet discovered that their so-called group Moschide is composed of two forms of animal life that have very little to do with one another. It has been shown most conclusively by the researches of $\mathrm{M}$. Alphonse Milne-Edwardst in Paris, and Prof. Flower in our own country, that the Cherrotains (Tragulus and Hyomoschus), one of the constituents of

* "Die Geographische Verbreit ung der Hirsche mit bezug auf die Geschichte der Polar-länder." Von Gustav Jaeger und Emil Bessels. (Petermann's Geographische Mittheilungen, 1870.)

$\dagger$ " Recherches Anatomiqueset Palæontologiques sur la famille des Chevrotains," Paris, 1864

I "Notes on the Visceral Anatomy of Hyomoschus aquetocus." Proc. Zool. Soc., 1867 . the Moschida of MM. Jaeger and Bessels, constitute a family per se, quite distinct from the rest of the ruminants, and connecting them with the pigs, and consequently quite distinct from the musk-deer (Moschus). In the same way our authors base certain arguments upon the fact of all the typical deer being spotted in the immature state. But, as Dr. Jaeger at least-having been, if we are not misinformed, custos of a zoological garden-ought to know, this is not quite the case, all the Rusine deer having their young spotless. Again, arguments are founded upon Cervus pudu of Chili living in the Cordilleras, and the other allied species with simple unbranched horns in the plains of South America. But exactly the contrary is the case. Cervus pudu is from the low maritime coast of Chili, ana one, if not more, of the so-called "Subulones" (C. rufius) lives high in the Andes of Venezuela and New Granada. From these and other similar instances of erroneous statements which it would be easy to point out, it is, in fact, quite obvious that the authors of this essay have no very special acquaintance with the group upon the distribution of which they treat. We leave it to naturalists to decide whether, under these circumstances, the results arrived at are worthy of much attention. Their theory seems to be that the deer-family reached the New World by an Arctic continent which formerly connected northern Europe with eastern America, and which Dr. Jaeger, in a former paper, has proposed to call "Arctis." There are, however, if we are not mistaken, equally good grounds for believing that the numerous, undoubtedly Old-world forms in North America reached it by immigration from North-western Asia.

\section{HENDERSON'S PATENT STEEL PROCESS}

TWO articles written by $\mathrm{Mr}$. W. Mattieu Williams, called "Papers on Iron and Steel-A Costly and Vexatious Fallacy," were published a short time since in NATURE. These papers are considered in this country to be the clearest and ablest that have ever appeared on this subject, setting forth the reason why all efforts heretofore made to produce steel from English cast-iron by partial decarbonisation have failed; that all manipulations have been directed to removing as much as possible the impurities contained in pig iron by oxidation. He was not aware that new agents have been used, combined with oxygen, and that patents had been granted therefor in England, Nos. 318, I,05I, A.D. I870 (which were not then published) for combining fluorine with oxygen, and fluorine combined with titanic acid, or with titanium and oxygen.

The new patent process for the production of steel by the partial decarbonisation of cast-iron consists in the combined use of fluorspar or other fluorides and titanic acid, applied to cast-iron at the melting temperatures, preferably in reverberatory furnaces. Fluorine is given off from the fluorspar, and is a more powerful agent for the removal of silicon than oxygen, and removes it almost entirely from the cast-iron before the reactions with the carbon begin; the phosphorus and sulphur are next acted upon and removed in the order they are named by means of the combined action of fluorine and titanic acid or fluorine, titanium, and oxygen, and lastly the carbon is removed. The fluorine is derived from fluorspar combined with iron ores containing titanic acid in such wise as ensures simultaneous action of the fluorine, titanium, and oxygen upon the cast-iron; and by reason of the affinities of these substances for silicon, phosphorus, sulphur, manganese, arsenic and carbon, these substances are taken from the iron in the form of vapour and slag, leaving the purified metal in the condition to be hammered or rolled as merchantable steel.

English pig-iron may be made direct into steel by the new process; and with the large class of irons smelted from hæmatites and specular ores with good fuel, pure 
steel may be made, that will be entirely desiliconised, dephosphorised, and desulphurised, and contain but the required amount of carbon to form steel of any particular degree of hardness, by arresting the decarbonisation of the metal whilst undergoing conversion.

Experiments were made in May last on a large scale at Messrs. Park, Brothers and Co.'s Steel Works, in Pittsburg, in boiling puddling furnaces fettled with such oxides, but without puddling or labour of stirring the iron during conversion; the only labour was that of "balling" and removing it from the furnace after the conversion was completed. The mode of application in the above-named establishment was $125 \mathrm{lb}$. of titaniferous iron ore (similar to the Norwegian) and 50 lb. of fluorspar, both in a powdered state, and then charging them evenly over the sole of the furnace. $475 \mathrm{lb}$. of No. 3 charcoal pig-iron, similar in quality to English hæmatite of Barrow, was then charged upon them, and, when melted, was allowed to remain without stirring or puddling. As soon as the pigiron melted, reactions began between the fluorspar and the titaniferous iron ore, and the silicon and phosphorus contained in the pig-iron. To ascertain exactly the conditions upon which the changes are made in the cast-iron whilst under treatment, samples were taken from the bath of liquid iron. The analysis of the first sample shows that the operation of the new process is entirely different from any other process, inasmuch as the silicon is entirely removed at the early stages of the process; and, with the silicon, phosphorus is also taken from the iron, and the carbon is changed from the graphitic to the combined form. Other samples were taken from the bath at intervals of ten minutes. The analysis of the first sample made it evident that most of the later ones were steel. This has since been confirmed by analysing a specimen taken thirty minutes later from the bath, and by the treatment of them as steel, it having been found that they possess the properties of steel, forging well, and tempering and hardening according to the various degrees of carbon contained in them. At the end of the operation, the charge became wrought-iron, by removal of all the carbon. This iron forges, welds, and is neither red-short nor cold-short.

The analyses of the first and fourth samples taken from the bath have been made by Mr. W. M. Habirshaw, analytical chemist, of 36 , New Street, New York, and are annexed. Also, analyses of Messrs. Sanderson's and Krupp's cast-steel, and Hoop L Dannemura-Swedish bar iron are annexed for comparison, taken from Dr. Percy's "Iron Metallurgy."
First. Sample. Refined Cast-iron,

Carbon, combined $2 \cdot 7144$ do graphite traces Slags (silicates) none

Silicon Phosphorus Sulphur

Titanium 0.0046 0.0349 0.1073

Fluorine taken 40 minutes after fusion.
Fourth Sample. Steel, taken 30 minutes later. Carbon, combined 0.2172 do graphite none Silicon none Phosphorus Sulphur Titanium very minute trace Fluorine Slags (silicates) none
Hoop L Bar-iron.

\section{Carbon}

Silicon

Phosphorus

Sulphur

Manganese

Arsenic trace

Cobalt, nickel none Copper none Aluminium none steel.

Carbon not deter. Silicon $\quad 0.24$ Phosphorus 0.02 Sulphur $\quad 0.05$ Manganese 0.03 Cobalt, nickel none Copper none Aluminium 0.12
Sanderson's Cast-
Krupp's Cast-steel.

Carbon

Silicon

0.02 Sulphur none Manganese trace Cobalt, nickel 0.12 $\begin{array}{ll}\text { Copper } & 0.30\end{array}$ Aluminium nou
From the foregoing analysis it will be seen that the refined cast-iron of the patent process contains but $\frac{1}{25}$ part of the silicon, less than one half the sulphur, and about the same amount of phosphorus, as compared with Hoop $\mathrm{L}$ bar-iron. This is the most celebrated wrought-iron made in the world, and is used exclusively for making steel, and sells at $24 l$. per ton at Sheffield.

The analysis of the steel of the patent process shows, as compared with Sanderson's and Krupp's, that while the latter are alloyed with carbon, silicon, sulphur, phosphorus, \&c., the steel of the new process is practically pure iron and carbon.

In the articles before referred to, written by $\mathrm{Mr}$. Williams (and from bis intimate practical and scientific knowledge no better authority can be had), he says :- "To make perfect steel they take out all these litter, and leave nothing but pure iron and carbon. Absolute perfection is not, of course, practically attainable in steel making, but it is approximated in the same degree as the purification of iron from everything except carbon is effected."

Persons wishing to satisfy themselves of the value of the process, by a test, should use the ordinary boiling puddling furnace, fettled with the purest red hæmatite or specular ores, containing the least silica, ground and applied wet, with the ordinary "bottom" made in the usual way : and when perfect steel is required, that contains neither silicon, phosphorus, nor sulphur, good pigiron should be taken, such as Nos. I and 2 Barrow, or West Cumberland hæmatite; and treated with pure fluorspar, and titaniferous iron ore from the Bay of St. Paul, in Canada, containing over 43 per cent. of titanic acid, or from Norway, containing over 40 per cent. of titanic acid ; using $48 \mathrm{lb}$. of fluorspar to I I $8 \mathrm{lb}$. of the ore. They should be ground to fine powder, and mixed, and used dry, and charged evenly over the sole or bottom of the furnace; and $475 \mathrm{lb}$. of pig-iron should be charged upon them, and the furnace closed tight so as to exclude all air, for about 70 minutes. The fire should be kept to the highest temperature. After the metal has been in the furnace this period, samples should be taken from the bath at intervals of five minutes. It will be found that a little experience will soon determine the proper time to stop the process.

It is best not to allow the workman attending the furnace to stir or puddle the metal during the conversion, as the fluorspar and titaniferous ore become viscid by the heat of the furnace by the time the pig-iron melts, and, if left alone, will remain on the bottom of the furnace until decomposed by the reactions of the process, when they pass through the iron as vapour and slag, and purify it more effectively than can be done by stirring or puddling ; and the slag serves to protect the surface of the metal from the effects of the sulphur in the fuel. The only labour that should be allowed is that of removing the steel from the furnace at the required stage of conversion.

The time in conversion of the steel, from the charging of the pig-iron, is one hour and 30 to 40 minutes; this time may be shortened 30 to 40 minutes, by previously refining the cast-iron of all its silicon and most of its phosphorus, by a shorter and more economical process (Patent, No. I, 05 I) with hæmatites and specular ores with florspar, which will become the subject of a future article.

New Yoik
JAMIES HENDERSON refined cast-iron, when treated with pure fluorspar, comes steel of superior quality when decarbonised below 1 ' 90 per cent of carbon. 